\title{
A placebo-controlled trial shows no effect of a vasopressin analogue (DGAVP) on subjective and cognitive recovery immediately after mild head injury
}

Citation for published version (APA):

Twijnstra, A., Bohnen, N., \& Jolles, J. (1992). A placebo-controlled trial shows no effect of a vasopressin analogue (DGAVP) on subjective and cognitive recovery immediately after mild head injury. Neurology, 42(S3), 328. [639P].

Document status and date:

Published: 01/01/1992

Document Version:

Publisher's PDF, also known as Version of record

Please check the document version of this publication:

- A submitted manuscript is the version of the article upon submission and before peer-review. There can be important differences between the submitted version and the official published version of record.

People interested in the research are advised to contact the author for the final version of the publication, or visit the DOI to the publisher's website.

- The final author version and the galley proof are versions of the publication after peer review.

- The final published version features the final layout of the paper including the volume, issue and page numbers.

Link to publication

\footnotetext{
General rights rights.

- You may freely distribute the URL identifying the publication in the public portal. please follow below link for the End User Agreement:

www.umlib.nl/taverne-license

Take down policy

If you believe that this document breaches copyright please contact us at:

repository@maastrichtuniversity.nl

providing details and we will investigate your claim.
}

Copyright and moral rights for the publications made accessible in the public portal are retained by the authors and/or other copyright owners and it is a condition of accessing publications that users recognise and abide by the legal requirements associated with these

- Users may download and print one copy of any publication from the public portal for the purpose of private study or research.

- You may not further distribute the material or use it for any profit-making activity or commercial gain

If the publication is distributed under the terms of Article 25fa of the Dutch Copyright Act, indicated by the "Taverne" license above, 
injured segmental structures was done after a 72 -hour recovery. Aspartate, GABA, glutamate, glycine, and taurine were measured before, during, and after prolonged transcranial motor cortex stimulation and quantified using HPLC.

Results. No changes in AANT levels occurred in either injury group from stimulation, compared to sham controls $(n=5)$. Severely injured flaccid animals had glycine levels $2-3$ times higher $(p<0$. mon than either mild/moderate, spastic animals or controls.

Conclusions. High concentration of the inhibitory AANT givcine is associated with flaccidity or SS but not spasticity. Clycinergic compounds directed toward suppression of excess muscle twonie in spastic conditions deserve further study.

\section{Ambulation with Functional Electrical Stimulation (FES) in Individuals with Paraplegia and Incomplete Quadriplegia}

Edward R. Chaplin, Encinitas, CA; M. Atrice, Atlanta, GA; D. Cardenas, Seattle, WA; R. Habasevich, Northfield, IL; R. Kogel, Hines, IL;

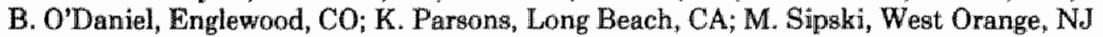

Commercial application of computer-assisted functional electrical stimulation (FES) is being promoted as a rehabilitation technology for motor disability. Experience with such devices has been primarily limited to research laboratories or those institutions participating in their development.

The Parastep System is a commercially available, bettery powered, microprocessor controlled, four- or six-channel stimulator which uses surface electrodes applied to skin to activate lower-extremity muscles for standing and taking steps. Programmed functions are initiated through switches located on the hand grips of a modified rolling walker. With training, users are able to assume and maintain a biped upright posture and activate reciprocal steps to achieve effective locomotion over level surfaces.

Between 1990 and 1992 the Parastep System was employed as an assistive device for walking in 41 individuals with paraplegia and incomplete quadriplegia. Malle to female ratio was 3:1. Sixty-one percent had complete thoracic cord injuries T12 or higher, $32 \%$ in. complete thoracic injuries and $7 \%$ incomplete cervical injuries belon C6. Twenty-five remain in the investigational program. Eleven could not complete training for medical or personal reasons. To date, $12 \%$ have completed 32 physical therapy sessions over an average of 18.5 weeks and are independent ambulators. This group ambulates with the device over 200 feet without resting.

Preliminary observations indicate that (1) independent ambuls. tion is possible in individuals with complete and incomplete paraplegia using a commercially available computer controlled $\mathbb{F E S}$ system; (2) patient motivation, pre-injury activity habits and general health status appear to correlate with successful ambulation; and (3) obstacles to successful ambulation include patient compliance, antitular changes and postural deformities.

\section{A Placebo-Controlled Trial Shows No Effect of a Vasopressin Analogue (DGAVP) on Subjective and Cognitive Recovery Immediately After Mild Head Injury}

A. Twijnstra, N. Bohnen, and J. Jolles, Maastricht, The Metherlands

Objective. The aim of the study was to investigate whether the administration of a behaviorally active neuropeptide (DGAVP) has a beneficial effect on the subjective and cognitive recovery from mild head injury.

Background. The vasopressin (VP) derivative DGAVP has consiatently failed to show a beneficial effect in patients with moderate to severe cognitive dysfunctions, but significant peptide effects have been found in various studies with healthy volunteers. There is a paucity of well-controlled studies of DGAVP in patients with only mild cognitive dysfunction.
Design. The study was performed according to a double-blind placebo-controlled matebed pairs design $(\mathbb{N}=36)$. The peptide was administered for 3 months (daily dose $2 \mathrm{mg}$ intra-nasal) starting fron the second day after mild head injury (MHI). There were 6 neuropsychological assessments.

Results. Repeated measures analysis of variance did not reveal a significant treatment effect for any of the cognitive parameters or subjective recovery.

Conclusions. The results of this study do not support the hypoth. esis that DGAVP may have a therapeutic effect in MHI patients.

\section{The Effect of Idebenone on Recovery from Stroke}

Steven J. Price, Solomon Kheyfets, and Michael d. Reding, White Plains, NY

Objective. Phase II trial of idebenone on recovery of neurollogic function following ischemic stroke.

Background. Idebenone is currently marketed in Japan to enhance recovery from stroke. Idebenone is thought to function as a coenzyme $Q$ analog, enhancing mitochondrial respiration and inhibiting lipid peroxidation in ischemic brain.

Design/Methods. This is a randomized, doublemblind, placebo. controlled study of patients admitted for inpatient rehabilitation following ischemic stroke. Outcome variables were assessed at baseline and 9 weeks, or upon discharge or withdrawal from study. Scores were compared with a two-tailed it test.
Results. Fifty-seven patients were enrolled a mean of $36 \pm 2$ (SEM) days post-stroke for a duration of $40 \pm 4$ days. Treatment and placebo groups were simillar at baseline. Final outcome variables lor the idebenone vs. placebo groups respectively were as follows: Burthel Index $68 \pm 4$ vs. $69 \pm 4$; Fugl-Meyer motor score $50 \pm 7$ 45. $62 \pm 6:$ Mini-Mental State $23 \pm 2$ vs. $25 \pm 1$; Western Aphasia Battery cortical quotient $80 \pm 6 \mathrm{vs.} 85 \pm 4$ and aphasia quotient $83 \pm 7 \mathrm{vs} .87$ \pm 5 ; and Hamilton Depression Scale $5 \pm 1$ vs. $4 \pm 1$.

Conclusion. We found no statistically significant beneft from the use of idebenone in the subacute phase post-stroke. 